\title{
Champagne, Cognac, Rioja, Jerez and Vales dos Vinhedos: Conflicts between trademarks and geographical indications of wines and spirits in Brazil
}

\author{
Patrícia Maria da Silva Barbosa ${ }^{1}$, Luiz Claudio Dupim² ${ }^{2}$ Kelly Lisandra Bruch ${ }^{3}$, and Patrícia Pereira Peralta ${ }^{4}$ \\ ${ }^{1}$ Instituto Nacional da Propriedade Industrial, Diretoria de Marcas, Rio de Janeiro, Brasil \\ ${ }^{2}$ Instituto Nacional da Propriedade Industrial, Diretoria de Contratos, GI e Registros, Rio de Janeiro, Brasil \\ ${ }^{3}$ Universidade Federal do Rio Grande do Sul, Centro de Estudos e Pesquisas em Agronegócios, Faculdade de Direito, Porto Alegre, \\ Brasil \\ ${ }^{4}$ Instituto Nacional da Propriedade Industrial, Academia de Propriedade Intelectual, Inovação e Desenvolvimento, Rio de Janeiro, \\ Brasil
}

\begin{abstract}
The world wine trade generated around 30 billion Euros in 2015. The wine consumer appreciates attributes such as tradition, quality and distinctiveness, characteristics that are associated with the terroir. In this segment, trademarks and geographical indications (GI) are relevant distinctive signs for the consumers' choice. Issues involving the protection of these signs have become increasingly stronger in the same proportion of the trade growth. Wine GIs hold a long tradition in the international scenario, particularly the European. In Brazil, the trademarks have a broader protection history, and the GIs were only acknowledged with the 1996 Industrial Property Law. Nevertheless, Brazil stands out as an emergent market for wines. The databank of the National Institute of Industrial Property (INPI-Brazil) shows that 30\% of all applications for GI protection are for wines and spirits. Such figures indicate the growing importance of the GI for the segment. The purpose of this paper is to analyze the applications for trademarks and GIs for wines and spirits, based on the INPI databank. For such, some foreign GIs have been chosen, for their historic and commercial importance, as well as one national GI, the first acknowledged in the segment. Among the results, several applications for trademarks from different applicants containing the searched terms have been found. From these results, it is believed that the coexistence and overlap of trademarks and GIs indicate the need for a review of the national legislation.
\end{abstract}

\section{Introdução}

The trade distinctive signs have a long tradition of use in view of the need for producers to mark their production, differentiating it from its competitors (SERENS, 2007).

However, the theme is marked by controversial issues related to the protection and coexistence of these signs. GI and marks, as distinctive signs, play an important role in the marketing of products such as wine and spirits in world trade. It is a sophisticated trade involving high numbers where the marks and GI are often decisive in the consumer's purchasing decision. Due to the high added value, such industrial property assets require an efficient protection system aimed at their integration in the markets in order to avoid the vulgarization and the loss of distinctiveness. Conflicts involving the use of these distinctive signs, such as the use of marks evoking producing wine regions, homonymous indications and terms considered generic, are intensified in proportion to the advancement of international trade.

Brazil is considered an emerging market in wine consumption. In this segment the GI enjoy international arena reputation, especially European. In Brazil these are now recognized positively only to the Industrial Property Law, Federal Law n. 9279/1996 (LPI). On the other hand, in Brazil the brands have a positive protection history dating from the nineteenth century. Brazil has strong influence of European settlement, especially in the regions of wine production, resulting in references to regions names of old wine world.

Research at the National Institute of Industrial Property (INPI) of Brazil database revealed that $30 \%$ of all GI applications for protection in Brazil are for the wines and spirits sector.

However, it presents a contradictory scenario in GI protection in Brazil. Many, when requesting the recognition of the INPI are faced with marks already registered.

On the other hand, the LPI allows the use of indicative terms such as "type", since the source is true except for similar products from the GI. This is achieved without any exception pair wines and spirits, which is contrary to TRIPS.

In this context, the aim of this study is to characterize this scenario by collecting and examining the applications for trademarks and GI applications for wines and spirits, based on the INPI database, including GI were considered not recognized in Brazil for this analysis. In order to attain the goal, the chosen methodology is qualitative.

This article does not address translations and graphic and phonetic variants of the terms that make up the GI. 
This analysis - stands out - does not reflect the institutional position, but rather reflections of the authors. Search is also confronting the existing literature on the subject with the content of decisions and procedures adopted by the INPI, so that such literature assist in the understanding of the cases.

\section{Wines and origin}

After the fall of the Roman Empire, Europe's regions more influenced by the Greco-Roman culture perfected the wine techniques. In the middle ages, the Catholic Church assimilated into its liturgy wine symbolism contributing to the development of vineyards and winemaking techniques. At this time, important locations like monasteries in Bourgogne, Citeaux, Clairvaux Eberbach, and Champagne region became famous for wine production.

With the advance of trade between nations and the European colonization of the Americas, also increases the consumption of wine, which is now widespread throughout the world. At the time of discovery and colonization expeditions, the vines reached other continents, adapted and began to provide good wines, especially in North America (United States), South America (Argentina, Chile and Brazil), Africa (South Africa) and Oceania (New Zealand and Australia).

The emergence of the Industrial Revolution and the rise of international trade, added to the importance of wine production and export of various European countries item, provided the need for protection of distinctive signs in the marketing of wines due to the increase in forgeries and counterfeits in the market.

Initially, concerned with protecting the indications of provenance, producers and wine exporting countries begin to invest in the promotion of typicality and product distinction characterized by its geographical characteristics. Come the denomination of origin (DO), which means the products whose qualities and characteristics were due to the geographical environment. Equally important, the producers of the regions that have achieved great notoriety began to invest in the promotion and protection of their brands acquired great value as intangible assets of companies. According to statistics of the International Organisation of Vine and Wine - OIV (2015), the global trade in wine moves a year, a figure close to 30 billion euros, of which approximately $40 \%$ of wine is consumed outside their country of origin. This fact denotes the value of factors related to the origin of the product in international trade in wine.

\subsection{Wine in Brazil}

In Brazil, wine production is established with the coming of German and Italian settlers to the south of the country in the nineteenth century. Initially, production was intended to meet domestic consumption needs, with a typical handicraft production with varieties Vitis labrusca and hybrid varieties called in Brazil "table wines". These still account for about $80 \%$ of the total volume of wine produced in the country (MELLO, 2013).

Later, with the growth of the internal market and the introduction of Vitis vinifera varieties, it went to wine production in Brazil called "fine wines", which began to compete directly with imported products (MELLO, 2013).

According to Mello (2013), the largest production of wine grapes is concentrated in the Serra Gaúcha of the Rio Grande do Sul state region, with great diversity of cultivated grapes and produced wine. This region accounts for about $90 \%$ of production of Brazilian wines.

With a strong influence of European colonization in the Brazilian wine industry, it is natural to use European references in the marketing of wine. Such references are with reference to brands or foreign GI may represent conflicts related to the signs distinctive the wine and spirits market in Brazil.

\section{The provisions of the LPI on the GI and its relationship with the brands}

The LPI innovated by allowing the positive protection of the GI in Brazil, through its recognition by the INPI. About the trademarks, the protection established by LPI is for products, service, collective and certification marks. All four types of marks can cause conflict with GI.

Although both are distinctive signs, these have similar, but different functions. The trademark is the distinctive sign more used by companies to distinguish their products and services on the market with the intention of attracting custom. Already, the GI aim to differentiate products that have a specific geographical origin of others who do not belong to the same geographical origin.

According to the LPI, the GI comprises e geographic name that has become known as a centre of production, extraction or production of a product (indication of provenance - IP) or the geographical name designating a product or service whose qualities or characteristics are due to through geographical (denomination of origin- DO).

As established in the paragraph of article 1 of the Instruction INPI n. 25/2013, the GI registration at INPI has a declaratory nature and involves the recognition of the GI. Therefore, according to Barbosa (2014), it is the recognition of a pre-existing right that allows holders the power to exclude others from the distinctive sign of use.

The relationship between GI and trademarks may be one of the main reasons to demand the GI registration by local producers who meet the LPI settings. From the official recognition of the GI, the marks requests analyst now has legal recourse at the administrative level for refusing requests containing GI elements. Including those that are referenced in the region, in view of the provisions of section IX of Article 124 of LPI 9279/96 (BRAZIL, 1996), as discussed in specific topic.

Thus, the GI registration gives holders to take legal action in order to exclude any third acts of "manufacture, import, export, sale, display or offer for sale or have in stock a product that presents a false GI" (DUPIM 2015 ).

However, despite offering some level of protection to GI, the LPI has some limitations in its scope of protection. In his article 180, LPI has a more flexible protection to the indication (in this case, the geographical name) when that became a common use. The article does not excepts the GI related to wine products as provided for in 
article 4, 1891 Madrid Agreement (with revisions in 1911, 1925 and 1958) relating to the use of false indications of provenance. This is observed a concern to provide additional protection to names applied to wine products which could not be regarded as generic in the signatory countries to the Agreement. The Brazil is a signatory of this originating.

Another important issue, which eases the use of GI as a brand element is contained in article 181, LPI. This enables the use of (geographic names) as characteristic marks element, provided it does not suggest a false source.

In relation to the latter legal provision, it is interesting to report that, in many countries of both the European as Anglo-Saxon law, geographical names are considered poor terms of distinctiveness, not being eligible for registration as a trademark, exactly because indicate the origin geographic product or service.

In Brazil, the LPI does not insert the geographical name as an absolute prohibition for trademark registration purposes. Depending on the LPI does not seal, it is not possible refuse protection of geographical names as trademarks. Examination procedures in place for this issue will be discussed in specific topic.

At Title IV of LPI, referring to crimes against industrial property, Chapter V refers to crimes against the GI and other indications. It is established in the LPI that is prohibited:

“Art. 192- Manufacturing, import, export, sale, display or offer for sale or have in stock a product that presents a false GI. "

Penalty - detention of 1 (one) to 3 (three) months or a fine."

"Art. 193 - Using, on a product, container, casing, belt, label, invoice, circular, poster or other means of disclosure or advertisement, indicative terms such as "type", "kind", "gender", "system" "like", "substitute", "identical", or equivalent, without making clear the true origin of the product.

Penalty - detention of 1 (one) to 3 (three) months or a fine."

"Art. 194- Use trademark, trade name, title of establishment, insignia, advertising expression or sign or any other form that indicates that not true, or sell or expose for sale a product carrying such signs. Penalty - detention of 1 (one) to 3 (three) months or a fine" (BRAZIL, 1996).

Thus, by allowing the use of indicative terms, the LPI eases again, the protection of the GI in that it allows the use of GI, or registered accompanied by terms like or equivalent, emphasizing their true origin.

This is also true in article 49, paragraph 2 of the Federal Law n. 7,678 / 1988, which regulates the wine in Brazil. Such flexibility in the scope of protection conflicts with the provisions of the TRIPS, where there is in its item 1 of article 23 an additional protection of GI identifying wines and spirits, even as regards the use of indicative terms.

As can be seen from the above reports, issues related to the use of GI for wines as a distinctive sign are diluted to the extent that the law allows their use in some cases, as a brand element or accompanied by indicative terms in the domestic market.

\section{Analytical overview of marks containing the geographical names study according to the Brazilian INPI}

As pointed by Barbosa, Dupim and Peralta (2016, p.180):

\begin{abstract}
"Regarding the examination and granting IG, LPI is silent with regard to preventing the recognition of a GI when a previously recorded mark. Thus, to the INPI, the existence of trademarks or required prior to the application for recognition of a GI are no impediments to the recognition of the latter. Part of it is assumed that, because it is declaratory record, the evidence of the reputation or influence of the geographical environment on the characteristics and qualities of the products or services are related to the location and sediment over time. INPI only recognizes a pre-established situation." (BARBOSA, DUPIM and PERALTA, 2016, p. 180).
\end{abstract}

However, the corporate position is different when it comes to protection under trademark. This is because the registration prohibitions of a trademark containing or consisting of GI or indicative terms of false provenance or origin are arranged in sections IX and X of article 124, LPI. That is, they are not registrable as trademarks:

[...] IX - geographic indications, imitations thereof likely to cause confusion or signs that might falsely suggest a GI; [and]

$\mathrm{X}$ - signs that suggest a false indication as to the origin, source, nature, quality or utility of the product or service to which the trademark [...]. (BRAZIL, 1996)

In addition, other registrability criteria for the application of these clauses is to make sure the suspicious names being GI are recognized or not in Brazil, as well as the trade mark applicant belongs to the locality of the GI.

Such analysis procedures are adopted for all brands, regardless of the nature and requested presentation. In addition, examination of the registrability of a mark is based on the principle of specialty, that is, there is a requirement to be verified marketing affinity between what is recognized as IG and being asked to be marked as a trademark.

Thus, inexistent legal obstacle to the granting of indicative sign composed of GI as a trademark in the case of the products or services are for different market segment. It is important to highlight that the marks are recorded as the International Classification (NICE) Products and Services for the Registration of Marks (NCL), which is divided according to the market segment. The GI, in turn, is protected according to the product or service, regardless of class and segment.

All applications for trademark registration and GI required at the INPI receive advertising through the Journal of Industrial Property (RPI). Weekly published, RPI discloses the requests made by the INPI, aiming to make possible the opposite manifestation of third parties, which may feel hurt. After the publication of the application, third parties have 60 days to present their objections, following the publication in the mentioned magazine.

Willing this overview on the subject of this work, let us analyse the scene found the bench marks and the INPI GI 
that are available in your Portal. As time criterion, it has been the month of June 2016.

\subsection{Champagne case}

The name "Champagne" began to be used to designate wines from the sixteenth century. Progressively, "Champagne" has established itself as the names of wines produced in the region.

Since the sixth century, local marketers seek to protect the name and engaged in numerous legal proceedings to prohibit other regions using that name.

The product is characterized by being a sparkling wine in which gasification takes place in a second elapsed fermentation directly into the bottle. This system became known as "méthode champenoise".

On August 4, 2011 the Committee Interprofessionnel $d u$ Vin de Champagne deposited the request for recognition Champagne as a GI in the kind of DO, in order to protect the geographical name in Brazil.

Under the IG201102 process, aimed at protecting sparkling wines. This process was opposed demonstration of the company "Winery Armando Peterlongo S.A". The protester claimed previously used the term in Champagne sparkling wine manufacture, and claimed that it should be considered in common use to describe the sparkling product in the domestic market, according to art. 180, LPI. At Brazilian Wine Federal Law n. 7.678/1998 is still used Champagne to designate a sparking wine.

The applicant contested the event, presenting proof of registration requirements and documents evidencing the acceptance of recognition of the Champagne designation by producers of domestic sparkling, except the opposition.

As established in Resolution 75/2000 (replaced by Instruction INPI n. 25/2013), the INPI decided by the approval of the application for registration in December 2012. However, it also recognized the prior use in good faith protester determining that it would not be hampered by the term protection, a fact that could lead to the cessation of the use of the same, ie, the protester could continue using it in their products.

In 2013 the same company, formerly opposing party, the Winery Armando Peterlongo SA, required examination on appeal against the granting of registration. Despite this fact, the recognition of the geographical name Champagne, such as designation of origin, was maintained.

The search for the INPI database for brands showed that there were 156 marks applied to the term "Champagne" for various classes until the end of the month of June 2016. That is, marks were found meant to designate various products such as cosmetics, clothing, jewelry and costume jewelry, as well as for food and events services. It is noteworthy that none of these deposits was carried out by the holder of the GI registration.

It is interesting to name the trademark for Guaraná "Guaraná Antartica Champagne" belonging to Companhia Brasileira de Bebidas, which has long been very popular in the country, that is now extinct.

To refine the search and focus only on the class comprising alcohol, or NCL (10) 33, there are 71 orders containing trademark term analysis. Of these, 18 brands belonging to different holders still are in the registration status in force, and only two records are owned by Armando Winery Peterlongo SA The earliest record was requested in October 1974. Ten cases still are pending examination, with the last application was recently filed: June 2016.

\subsection{Cognac case}

In March 1998, the Bureau National Interprofessionnel du Cognac deposited in INPI the application for registration for the geographical name "Cognac" as a GI in the species designation of origin.

Following, the Brazilian Association of Beverages (ABRABE) filed an opposition against the registration of the GI in INPI. He claimed that the term "conhaque" used in Brazil, referred to the drink derived from fermented juice of distillation of sugar cane, plus tar, honey and ginger. And though many producers of national drinks used on their labels the term "conhaqu" there are long dates, citing as examples the traditional brands in Brazil, such as Straw, Dreher, São João da Barra, Don Bosco and Presidente. It stated further that it was a different drink, considering that the product designated by the term Cognac claimed came from the distillation of wine, despite the phonetic similarity.

The demonstrator, based on case law and legislation: Law 549/37, Decree 2499/38, Decree 3582/41, Decree 4327/42, Decree 39976/56, Law 7678/88, Law 8918/94, Decree 2314/97, requested the application of art. 180 of the LPI, arguing that "conhaque" in Brazil, had become common use and therefore "Cognac" could not be regarded as GI.

According to INPI, it is striking the absence of competition between French vinous distilled Cognac and the national product consists of the distillate from the fermentation of sugarcane with honey, ginger, tar and other products.

Thus, INPI recognized the Cognac denomination of origin for vinous distillate produced in the eponymous region. And preserving the rights previously acquired in good faith, authorized the use of the word brandy expressly in national alcohol.

The search for the INPI database for brands showed that there were 19 marks applied to the term "Cognac" for various classes until the end of the month of June 2016. Again appeared deposits marks to mark cosmetics (2) and apparel (1) as for the case "Champagne" described above. But it was also located an order to mark sails for boats. Counter point, no marks for service found. The vast majority of applications, that is, 16 cases $(84 \%)$ were noted for alcoholic beverages.

Again, none of these deposits was carried out by GI registration holder in his country of origin, as the case found in "Champagne" described above.

Three cases of different applicants filed by June 2016 are still pending examination.

Only four records are in force, two for the alcoholic beverage segment, one for non-alcoholic beverages and clothing.

Considering the particularity of the court decision was made search in the class related to alcohol for the term "conhaque", in exception to the procedure adopted for the other terms. 74 makes deposits were found. And of those, 20 are records belonging to different holders. 


\subsection{Rioja case}

The search criterion in temporal database with June 2016 demonstrated the existence of 35 cases filed with the term "Rioja" in different classes. Such a request, filed in March 1999 requested by the Consejo regulator denominator calificada origin "RIOJA" even requesting that years later, in 2012, required the recognition of the GI in Brazil.

This application for registration as a trademark was dismissed in 2002 by items IX and X, as noted by the examiner that it was brand containing GI recognized in their country of origin (Spain). We had the interpretation that the item IX of article 124, LPI, expressed absolute prohibition to be no exception about different treatment to residents in the protected area. It should be noted that such a restrictive interpretation of the clause in question remains in force at the INPI until the time of completion of this study.

Almost a decade later, in 2012, the same trade mark applicant, requested the INPI recognition of "Rioja" name as a designation of origin, but recognition has not happened because the request is taken pending on demand function held the technical sector. However, while still pending decision, the recognition request can already be considered an impediment to the grant of the term as a trademark. This is because the INPI's procedure defer trademark applications containing the name required as GI, pending examination.

According to Barbosa, Dupim and Peralta (2016):

"For registrability purposes trademarks containing imitation or reproduction of IG with recognition requested the INPI is still pending decision, the municipality, through its brands Board is elected to maintain the application halted trademark registration by decision request $\mathrm{IG}$. As in previous cases, this procedure is being applied independently to be the applicant for the mark the same IG." (BARBOSA, DUPIM and PERALTA, 2016, p. 175).

The same authors point out that this procedure is adopted by INPI because it is considered that the registration of the GI is the recognition of a fact of law. Thus the application for trademark registration is kept halted until completion of the GI registration application of the procedure.

Regarding the time criterion, required marks were observed prior to request recognition as a GI, the first request dated record of September 1948. The same is now extinct.

Eight trademark registrations containing the word Rioja are in force, and only two for alcoholic beverages and Spanish entitlements. Only one is for cargo transportation service (from Brazil holder), while others are intended to point out fruit, vegetables and cereals, condiments, spices and food essences, as well as its trade and belong to the same holder Brazilian origin.

\subsection{Caso Jerez}

The name "Jerez" is the oldest Spanish IG. However, this GI differs from the others, since the recognition of the geographical term has not yet been requested in Brazil.

As done with other GI discussed so far, we sought to identify whether the term "Jerez" composed some mark. They were located 8 marks made by that term. Of these, only one is not directed to products or food service, for it tried to point out garments.

Four were intended for alcoholic beverages segment, with all four of Spanish origin. Of these only one met the former record, with the three remaining in force at the time of closing of this study and all having been requested in June 2005 by the same Spanish company. It stresses that the said company is not the owner of the GI of the right to use "Jerez" recognized as IG in the European Union.

Currently when the registrability of marks containing GI not recognized in the country, the INPI guides the decision of the examination by observing whether the brand applicants are established in the locality of GI or not. This is because if the applicant find yourself actually in the region, granting the required sign as a trade mark is possible. When the trademark applications were claimed by the applicant in a different region, such signs may be denied on the basis of item X of article 124, LPI. This is considered a false source.

However, for the rejection occurs is necessary that the GI is identified in any way. This is because, according to LPI 9279/96, the sign is liable to be registered as a trademark when it is composed of geographical name devoid of reputation for being requested, provided they do not incur other legal prohibitions as art. $181 \mathrm{LPI}$.

It is noteworthy, therefore, it is crucial that GI holders be attentive to make known by the means provided by the municipality. I.e. filing opposition demonstration to the registration of the mark when the first examination or filing administrative nullity proceedings, after registration, which is analysed by the second administrative level. In the example "Jerez" GI have been recognized in the regional bloc of origin, but not national and therefore liable to be registered as a trademark, which, in fact, happened. There are three registered trademarks by third parties in Brazil today, which are made by that term.

\subsection{Vale dos Vinhedos case}

The first Brazilian GI is an interesting case study. The term is present in 16 marks applied into several classes, the same having been found in the search performed in the INPI trademarks database. Of these, two have been requested by the representative of GI in Brazil, both for alcohol. The first deposit occurred in April 1991 and the second in January 2000. Both are no longer in force because the first record had not required its extension and the second suffered withdrawal even before became a registration by your applicant. One can therefore conclude that the Association of fine wine producers in the Vale dos Vinhedos - APROVALE, considered that the most appropriate course of their wishes was to ask for protection as indication of origin of the name "Vale dos Vinhedos". Thus, they declined brands under their ownership after the recognition of IP, opting for yet require the same expression as designation of origin a few years after the recognition of IP.

For Barbosa (2003), LPI presents a treatment of the two figures as being parallel and with different concepts: in the case of IP, it is related to the place which has become known, and in the case of this is related the product designated by the local name whose characteristics are 
due to the geographical environment. Barbosa, Dupim and Peralta (2016) discuss:

"This definition through two parallel species enables the occurrence of some cases of overlapping records, such as in cases of "Vale dos Vinhedos' and 'Cerrado Mineiro.' Both were recognized as and IP by the INPI. Because it is an acknowledgment, the record is not subject to withdrawal or expiration. Therefore, by failing to provide limitations or overlapping, the coexistence of these two types of GIs, ie the same geographical name be recognized as IP and DO, can cause double protection. Considering the lack of these figures by the consumer public, questions the effectiveness of this protection. This without considering also the possibility of overlap with brands [...]." (BARBOSA, DUPIM and PERALTA, 2016, p.183).

No trademark registration is in force on the INPI containing the geographical name "Vale dos Vinhedos". Fifteen applications have been filed or extinct and one is still pending examination, it is recent, it has been filed in March 2016.

Fifteen of these applications, only one, the own APROVALE, was intended to alcohol. The others were distributed to the various classes being one to mark cosmetics seven to mark food products such as dairy products, meats, eggs, pastries, fruit and vegetables, among others. The remaining deposits were intended to point out several services that comprised from holding events trade services, business administration, advertising and even food services, among others. It was also observed that most of these deposits were made by a single company resident in the area protected by the GI. The reasons for filing were not raised.

\section{Discussion}

To facilitate the visualization of the results found here and discussed, the Table 1 was elaborated, provides an overview of the situations, correlating GI with brands found:

Table 1 analysis identifies the existence of several trademark applications from different applicants containing the names in the study. Champagne with the largest number of marks applied reached 156 deposits marks.

At Second place was to Rioja, with 35 deposits. At this juncture, it is believed that the coexistence between trademarks and GI, as well as records of the same geographical name such as IP and DO contribute to cause confusion among consumers as to the signs with which they are faced, as well as dilution of the same signs in the market.

It was noted that the registration as a geographical impediment brand name protected as a GI done more effectively when the GI is recognized in the INPI. Jerez is an example because, although GI recognized in the European Union, the term in question is an integral part of three registered trademarks by third parties in Brazil.

\section{Final considerations}

GI and marks as distinctive signs are of great importance in the differentiation and aggregation of intangibles in the
Table 1. GI and trademarks correlation related with the application of that at INPI BR. Source: Authors.

\begin{tabular}{|c|c|c|c|c|c|}
\hline \multicolumn{2}{|r|}{ GI } & \multicolumn{4}{|c|}{ Trademark } \\
\hline $\begin{array}{l}\text { C } \\
\text { H }\end{array}$ & \multirow{3}{*}{$\begin{array}{c}\text { Recognized } \\
\text { by } \\
\text { INPI BR }\end{array}$} & \multicolumn{2}{|c|}{$\begin{array}{l}\text { Required by } \\
\text { a third part }\end{array}$} & \multicolumn{2}{|c|}{$\begin{array}{l}\text { Required by the same } \\
\text { applicant of the GI }\end{array}$} \\
\hline \multirow{2}{*}{$\begin{array}{l}\mathbf{M} \\
\mathbf{P} \\
\mathbf{A} \\
\mathbf{G} \\
\mathbf{N} \\
\mathbf{E}\end{array}$} & & application & $\begin{array}{c}\text { current } \\
\text { trademark }\end{array}$ & application & $\begin{array}{c}\text { current } \\
\text { trademark }\end{array}$ \\
\hline & & 156 & 18 & - & - \\
\hline \multirow{3}{*}{$\begin{array}{l}\mathbf{C} \\
\mathbf{O} \\
\mathbf{G} \\
\mathbf{N} \\
\mathbf{A} \\
\mathbf{C}\end{array}$} & \multirow{3}{*}{$\begin{array}{c}\text { Recognized } \\
\text { by } \\
\text { INPI BR }\end{array}$} & \multicolumn{2}{|c|}{$\begin{array}{l}\text { Required by } \\
\text { a third part }\end{array}$} & \multicolumn{2}{|c|}{$\begin{array}{l}\text { Required by the same } \\
\text { applicant of the GI }\end{array}$} \\
\hline & & application & $\begin{array}{c}\text { current } \\
\text { trademark }\end{array}$ & application & $\begin{array}{c}\text { current } \\
\text { trademark }\end{array}$ \\
\hline & & 18 & 4 & - & - \\
\hline \multirow{3}{*}{$\begin{array}{l}\text { R } \\
\text { I } \\
\text { O } \\
\text { J } \\
\text { A }\end{array}$} & \multirow{3}{*}{$\begin{array}{c}\text { Recognized } \\
\text { by } \\
\text { INPI BR }\end{array}$} & \multicolumn{2}{|c|}{$\begin{array}{l}\text { Required by } \\
\text { a third part }\end{array}$} & \multicolumn{2}{|c|}{$\begin{array}{l}\text { Required by the same } \\
\text { applicant of the GI }\end{array}$} \\
\hline & & application & $\begin{array}{c}\text { current } \\
\text { trademark }\end{array}$ & application & $\begin{array}{c}\text { current } \\
\text { trademark }\end{array}$ \\
\hline & & 35 & 8 & 1 & - \\
\hline \multirow{3}{*}{$\begin{array}{l}\mathbf{J} \\
\mathbf{E} \\
\mathbf{R} \\
\mathbf{E} \\
\mathbf{Z}\end{array}$} & \multirow{3}{*}{$\begin{array}{c}\text { Not } \\
\text { Recognized } \\
\text { by } \\
\text { INPI BR }\end{array}$} & \multicolumn{2}{|c|}{$\begin{array}{l}\text { Required by } \\
\text { a third part }\end{array}$} & \multicolumn{2}{|c|}{$\begin{array}{l}\text { Required by the same } \\
\text { applicant of the GI }\end{array}$} \\
\hline & & application & $\begin{array}{c}\text { current } \\
\text { trademark }\end{array}$ & application & $\begin{array}{c}\text { current } \\
\text { trademark }\end{array}$ \\
\hline & & 8 & 3 & - & - \\
\hline $\begin{array}{l}\mathbf{V} \\
\mathbf{A}\end{array}$ & \multirow[b]{3}{*}{$\begin{array}{c}\text { Recognized } \\
\text { by } \\
\text { INPI BR }\end{array}$} & \multicolumn{2}{|c|}{$\begin{array}{l}\text { Required by } \\
\text { a third part }\end{array}$} & \multicolumn{2}{|c|}{$\begin{array}{l}\text { Required by the same } \\
\text { applicant of the GI }\end{array}$} \\
\hline $\begin{array}{l}\text { E } \\
\text { D }\end{array}$ & & application & $\begin{array}{l}\text { current } \\
\text { trademark }\end{array}$ & application & $\begin{array}{l}\text { current } \\
\text { trademark }\end{array}$ \\
\hline $\begin{array}{l}\text { S } \\
\mathbf{V} \\
\mathbf{I} \\
\mathbf{N} \\
\mathbf{H} \\
\mathbf{E} \\
\mathrm{D} \\
\mathbf{O} \\
\mathbf{S}\end{array}$ & & 14 & - & 2 & - \\
\hline
\end{tabular}

wine and spirits market, as consumers identify qualities and characteristics depending on the origin of goods, whether geographic or business.

It was found in research that the concept of GI was first developed in Europe, from the wine industry. Multilateral and bilateral agreements agreed over the years sought to ensure the right to exclusive use of these distinctive signs from its recognition as a GI protected in international trade.

The concept of GI, in the case of Brazil, only consolidated in the national legislation from the LPI 9279/96, which is a result of the internalization of the TRIPS Agreement in Brazil. Despite the commitment to the country's accession to the agreement of the World Trade Organization, the national legislation does not internalized the definition of GI present in TRIPS in its entirety by restricting the protection only to geographical names, as defined in Chapter IV of the LPI n. 9279 / 96.

Despite having brought innovation in the field of distinctive signs, the LPI leaves questions still not pacified regarding the interaction between brands and GI and the use of the latter in a market with strong influence of European settlement, as is the case of Brazil.

This study allowed several situations could be identified. They found examples from brands granted before the recognition of the GI in the country (or even 
their classification in law) to cases where the recognition of the GI may come across the earlier trademark protection. INPI, for examination of trademark signs, is mainly based on GI recognition of existence in Brazil to prohibit the registration as a brand name consisting of GI. Therefore, the internal recognition of the GI by that institute entails the protection of the geographical name more effectively by allowing such a name to be identified as GI at the exact moment of the trademark examination, invalidating it. In the absence of recognition in Brazil, the holder of GI risks to the identification name as GI does not occur, allowing the term or expression to be registered as a trademark.

This behaviour on the part of the GI holders allows the existence of the scenery found in this study. Trademarks containing geographical names registered prior to the recognition of a particular place and GI remain living with the GI registration, providing confusion by consumers in view of the functions of these signs are very close.

Besides the confusion pointed out that the coexistence of these signs can generate, the coexistence of both protections for the same sign can lead to dilution of this distinctive sign, causing emptying.

Although the protection of the brand tradition is more consolidated in Brazil, recognizing the latest GI, they enjoy a significant economic importance in the segment discussed here in relation to the international scene. Therefore, it is emphasized that it is for the GI holders are attentive to the defence, the Brazilian market, these valuable signs in the international market.

\section{References}

BRASIL, Ministério do Desenvolvimento, Indústria e Comércio Exterior (MDIC), Instituto Nacional da Propriedade Industrial. Resolução 142/2014 de 27 de nov. de 2014. Dispõe sobre a criação do Manual de Marcas. Disponível em: http://www.inpi.gov.br/ manualdemarcas.inpi.gov.br/.../ RES_ 142/ 2014_Manual_de_Marcas.pdf Acesso em: 12 jan. de 2016

—a. Ministério do Desenvolvimento, Indústria e Comércio Exterior (MDIC), Instituto Nacional da Propriedade Industrial. Instrução Normativa 25/2013 de 12 de nov. de 2013. Estabelece as condições para o Registro das GI. Disponível em: http://www.inpi.gov.br/legislacao-1/in_25 21_de_agosto_de_2013.pdf. Acesso em: 12 jan. de 2016

—. Decreto 2314/97, de 4 de Setembro de 1997 Regulamenta a Lei ${ }^{\circ} 8.918$, de 14 de julho de 1994, que dispõe sobre a padronização, a classificação, o registro, a inspeção, a produção e a fiscalização de bebidas. Diário Oficial [da] República Federativa do Brasil. Seção 1. 05/09/1997. p. 19549

—. Lei $\mathrm{n}^{o}$. 9.279, de 14 de maio de 1996. Regula direitos e obrigações relativos à propriedade industrial. Diário Oficial [da] República Federativa do Brasil, Brasília, DF, 15 mai. 1996. Disponível em: http://www.planalto.gov.br/ccivil_03/leis/ 19279.htm. Acesso em: 12 de jan. de 2016

—_. Lei 8918/94, de 14 de Julho de 1994 - Dispõe sobre a padronização, a classificação, o registro, a inspeção, a produção e a fiscalização de bebidas, autoriza a criação da Comissão Intersetorial de Bebidas e dá outras providências. Diário Oficial [da] República Federativa do Brasil. Seção 1. 15/07/1994. p. 10661

—. Lei 7678/88, de 8 de novembro de 1988 - Dispõe sobre a produção, circulação e comercialização do vinho e derivados da uva e do vinho, e dá outras providências. Diário Oficial [da] República Federativa do Brasil. Seção 1. 09/11/1988. p. 21561

—. Lei $\mathrm{n}^{\circ}$ 5.772, de 21 de dezembro de 1971. Instituiu o Código da Propriedade Industrial, e dá outras providências. Diário Oficial [da] República Federativa do Brasil, Brasília, DF, 31 dez. 1971. Disponível em: http://www.planalto.gov.br/ccivil_03/LEIS/ L5772.htm Acesso em: 12 jan. de 2016

—. Decreto 39976/56, de 12 de Setembro de 1956 Aprova o regulamento para a fabricação e comércio de vinhos seus derivados e bebidas em geral, a que se refere a Lei ${ }^{\circ} 2.795$, de 12 de junho de 1956. Diário Oficial [da] República Federativa do Brasil. Seção 1. 17/09/1956. p. 17666

—. Decreto-Lei n ${ }^{\circ}$ 4.327/42, de 22 de Maio de 1942 - Dispõe sobre o uso da denominação "conhaque". Diário Oficial [da] República Federativa do Brasil. Seção 1. 25/05/1942. p. 8481

—. Decreto 2499/38 de 16 de março de 1938 - Aprova o regulamento da fiscalização da produção, circulação e distribuição do vinho no Brasil. Diário Oficial [da] República Federativa do Brasil. Seção 1. 28/03/1938. p. 5790

— Lei 549/37 de 20 de outubro de 1937 - Dispõe sobre a fiscalização da produção, circulação e distribuição de vinhos e derivados. Diário Oficial [da] República Federativa do Brasil. Seção 1. 26/10/1937. p. 2149

BUREAU NATIONAL INTERPROFESSIONNEL DU COGNAC - Pedido de registro para o nome geográfico COGNACs na espécie Denominação de Origem. IG980001, INPI - 12 de mar. 1998

COMITÉ INTERPROFESSIONNEL DU VIN DE CHAMPAGNE - Pedido de registro para o nome geográfico CHAMPAGNE na espécie Denominação de Origem. IG201102, INPI - 04 de ago. 2011

D. B. BARBOSA, Introdução à Propriedade Intelectual. Revisão dos textos anteriores de 1996 e 2003. Disponível em: http://www.denisbarbosa.addr. com/arquivos/200/propri edade/da_titularid ade_multipla.pdf . Acessado em dezembro - 2014

_Uma introdução à propriedade intelectual: introdução, aspectos constitucionais, direito internacional, teoria da concorrência, Patentes, segredo industrial, cultivares, topografia de semicondutores, proteção de conhecimento e criações tradicionais, conceito de propriedade industrial e transferência de tecnologia. 2.ed. Rio de Janeiro: Lumens Júris, 2003. EMBRAPA Uva e Vinho - Disponível em: www.embrapa.br/uva-e-vinho. Acessado em novembro de 2014

J. HUGH. The Story of Wine, Ed. Mitchell-Beazley, Londres 1989

J. O. ASCENSÃO, "Direito intelectual, exclusivo e liberdade". Revista da ABPI. Rio de Janeiro, n.59, p.40-49, jul/ago. 2002 
L. C. DUPIM, - GI e desenvolvimento local: estudo exploratório e comparativo das GI Vale dos Vinhedos, Região do Cerrado Mineiro e Paraty. Tese (doutorado) - Universidade Federal do Rio de Janeiro, Instituto de Economia, Programa de Pós-Graduação em Políticas Públicas, Estratégias e Desenvolvimento, 2015

L.M. R. MELLO- Vitivinicultura Brasileira: Panorama 2012. Embrapa Uva e Vinho, Comunicado Técnico 137. ISNN 1808-6802, Bento Gonçalves/RS, junho de 2013

M. C. N. SERENS. A monopolização da concorrência e a (re) emergência da tutela da marca. Coimbra: Almedina, 2007
OIV - International Organization of Vine and Wine. Disponível em: http://www.oiv.int/en/ databases-and- statistics/statistics. Acessado em : 12 jul. 2016

P. M. S BARBOSA, L. C. DUPIM, P. P. PERALTA, Marcas e GI: conflitos de registrabilidade nos 20 anos da LPI. In: LOCATELLI, L. (Org). GI: desafios e perspectivas nos 20 anos da Lei de Propriedade Industrial. Rio de Janeiro: Editora Lumen Júris. 2016

p. 157-188. Disponível em: https://www. researchgate.net/publication/306097468_ MARCAS_E_INDICACOES_GEOGRAFICAS_CONFLITOS DE_REGISTRABILIDADE_NOS_20_ANOS_DA_LEI_DA_ PROPRIEDADE_INDUSTRIAL_LPI?ev=prf_pub 